\title{
Production and storage stability of concentrated micellar casein
}

\author{
Ahmed R. A. Hammam, ${ }^{*}$ (teven L. Beckman, and Lloyd E. Metzger $\odot$ \\ Dairy and Food Science Department, South Dakota State University, Brookings 57007
}

\begin{abstract}
Concentrated micellar casein $(\mathrm{CMC})$ is a highprotein ingredient that can be used in process cheese product formulations. The objectives of this study were to develop a process to produce CMC and to evaluate the effect of sodium chloride and sodium citrate on its storage stability. Skim milk was pasteurized at $76^{\circ} \mathrm{C}$ for $16 \mathrm{~s}$ and cooled to $\leq 4^{\circ} \mathrm{C}$. The skim milk was heated to $50^{\circ} \mathrm{C}$ using a plate heat exchanger and microfiltered with a graded permeability (GP) ceramic microfiltration (MF) membrane system $(0.1 \mu \mathrm{m})$ in a continuous feed-and-bleed mode (flux of $71.43 \mathrm{~L} / \mathrm{m}^{2}$ per hour) using a $3 \times$ concentration factor $(\mathrm{CF})$ to produce a $3 \times$ MF retentate. Subsequently, the retentate of the first stage was diluted $2 \times$ with soft water $(2 \mathrm{~kg}$ of water: $1 \mathrm{~kg}$ of retentate) and again $\mathrm{MF}$ at $50^{\circ} \mathrm{C}$ using a $3 \times$ $\mathrm{CF}$. The retentate of the second stage was then cooled to $4^{\circ} \mathrm{C}$ and stored overnight. The following day, the retentate was heated to $63^{\circ} \mathrm{C}$ and $\mathrm{MF}$ in a recirculation mode until the total solids (TS) reached approximately $22 \%$ (wt/wt). Subsequently, the MF system temperature was increased to $74^{\circ} \mathrm{C}$ and $\mathrm{MF}$ until the permeate flux was $<3 \mathrm{~L} / \mathrm{m}^{2}$ per hour. The CMC was then divided into 3 aliquots (approximately $10 \mathrm{~kg}$ each) at $74^{\circ} \mathrm{C}$. The first portion was a control, whereas $1 \%$ of sodium chloride was added to the second portion (T1), and $1 \%$ of sodium chloride plus $1 \%$ of sodium citrate were added to the third portion (T2). The CMC retentates were transferred hot to sterilized vials and stored at $4^{\circ} \mathrm{C}$. This trial was repeated 3 times using separate lots of skim milk. The CMC at d 0 (immediately after manufacturing) contained $25.41 \%$ TS, $21.65 \%$ true protein (TP), $0.09 \%$ nonprotein nitrogen (NPN), and $0.55 \%$ noncasein nitrogen $(\mathrm{NCN})$. Mean total aerobic bacterial counts (TBC) in control, $\mathrm{T} 1$, and $\mathrm{T} 2$ at $\mathrm{d} 0$ were $2.6,2.5$, and $2.8 \log \mathrm{cfu} / \mathrm{mL}$, respectively. The level of proteolysis (NCN and NPN values) increased with increasing TBC during $60 \mathrm{~d}$ of storage at $4^{\circ} \mathrm{C}$. This study
\end{abstract}

Received August 24, 2021.

Accepted October 18, 2021.

*Corresponding author: ahmed.hammam@sdstate.edu determined that CMC with $>25 \%$ TS and $>95 \%$ casein as percentage of TP can be manufactured using GP MF ceramic membranes and could be stored up to $60 \mathrm{~d}$ at $4^{\circ} \mathrm{C}$. The effects of the small increase in NCN and NPN, as well as the addition of sodium chloride or sodium citrate in CMC during $60 \mathrm{~d}$ of storage on process cheese characteristics, will be evaluated in subsequent studies. Key words: microfiltration, micellar casein, shelf-life, proteolysis

\section{INTRODUCTION}

Microfiltration (MF) is a membrane process used to separate CN micelles $(0.1-0.40 \mu \mathrm{m})$ and serum whey proteins (SP; 0.003-0.010 $\mu \mathrm{m}$ ) from skim milk, using a semipermeable membrane with a pore size of $0.1 \mu \mathrm{m}$. When MF is applied to skim milk, $\mathrm{CN}$ is concentrated in the retentate and called micellar casein concentrate (MCC), whereas SP, lactose, soluble minerals, and water pass through the membrane to the permeate. The CN in the MCC exists in a micellar form, which is a relatively stable colloidal dispersion (Rollema and Muir, 2009).

Micellar casein concentrate has been manufactured from skim milk using different MF membranes, such as polymeric spiral-wound (SW) membranes (Govindasamy-Lucey et al., 2007; Lawrence et al., 2008; Zulewska et al., 2009; Beckman et al., 2010; Beckman and Barbano, 2013; Hammam et al., 2021; Marella et al., 2021) or ceramic membranes, including uniform transmembrane pressure (UTP) and graded permeability (GP) membranes (Zulewska et al., 2009; Hurt and Barbano, 2010; Hurt et al., 2010; Adams and Barbano, 2013, 2016; Zulewska and Barbano, 2014; Hammam and Metzger, 2018). The SW membranes are less expensive and have lower operating costs but have limited viscosity range, low chemical stability, and shorter life compared with ceramic membranes (Zulewska et al., 2009; Hammam et al., 2021). In a study that compared different MF membranes, the flux was higher in UTP and GP ceramic membranes ( 54 and $72 \mathrm{~L} / \mathrm{m}^{2}$ per hour, respectively) than in $\mathrm{SW}$ membranes $\left(16 \mathrm{~L} / \mathrm{m}^{2}\right.$ per hour) when skim milk was $\mathrm{MF}$ at $50^{\circ} \mathrm{C}$ in a continuous feed-and-bleed mode using a $3 \times$ concentration factor 
(CF; Zulewska et al., 2009). That study also reported that the efficiency of SP removal was 39\% for SW, $64 \%$ for UTP, and $61 \%$ for GP MF membranes. To achieve SP removal with SW membranes comparable to that of ceramic membranes, more membrane surface area and diafiltration (DF) stages would be required (Zulewska et al., 2009; Hammam et al., 2021). As a result, UTP and GP ceramic membranes are widely used for MF of skim milk. Uniform transmembrane pressure membranes require a higher investment and operating costs relative to GP membranes, due to the need for a permeate recirculation pump to produce co-current permeate flow, and thereby decreasing the fouling and increasing the SP removal (Zulewska et al., 2009; Hammam et al., 2021). By contrast, GP membranes eliminate the need for a permeate recirculation pump and the associated electrical costs, due to their ability to maintain a constant and uniform flux.

Micellar casein concentrate is a high-protein ingredient that can be used in a range of commercial applications, including protein fortification of dairy foods and ingredients for beverages, bakery, and meat products, due to its unique physicochemical and functional properties (e.g., water-binding, emulsifying, whipping, and foaming properties; Mulvihill and Ennis, 2003). The typical composition of liquid $\mathrm{MCC}$ is $>9 \%$ true protein (TP) and $>13 \% \mathrm{TS}$, using $3 \mathrm{MF}$ stages with a $3 \times \mathrm{CF}$ and DF (Zulewska et al., 2009). It has been reported that the first $3 \times \mathrm{CF}$ MF stage using GP and UTP membranes produced MCC with 14.16 and $15.04 \%$ TS, respectively, and TP of 8.03 and $8.86 \%$, respectively (Zulewska et al., 2009; Hurt et al., 2010; Zulewska and Barbano, 2014; Tremblay-Marchand et al., 2016). The MCC produced from the second $3 \times \mathrm{CF}$ MF stage using GP and UTP MF system had 10.30 and $11.41 \%$ TS, respectively, with TP of 7.5 and $8.68 \%$, respectively (Hurt et al., 2010; Zulewska and Barbano, 2014; Tremblay-Marchand et al., 2016). This MCC can be used as-is in many applications, or it can be further concentrated to produce concentrated micellar casein (CMC).

The MCC can be further concentrated using UF with a $2.2 \times \mathrm{CF}$, followed by $3 \mathrm{MF}$ stages with a $3 \times \mathrm{CF}$ with DF, followed by UF again for further concentration (Amelia and Barbano, 2013) to produce CMC with 18 and $22 \%$ TP and TS, respectively. Micellar casein concentrate can also be concentrated by using vacuum evaporation. Lu et al. (2015) reported that CMC containing $>25 \%$ TS and $>20$ TP can be produced using $\mathrm{MF}$ and vacuum evaporation. It may be possible to use GP MF membranes to produce CMC instead of using a combination of different equipment. Micellar casein concentrate and CMC can also be dried to produce
MCC powder with a long shelf-life that has $84 \%$ TP and $96 \%$ TS (Nasser et al., 2018). If CMC is left in a concentrated form, it eliminates the drying cost and has more solubility compared with dried MCC. However, CMC has a shorter shelf-life as well as increased transportation costs compared with dried MCC (Amelia and Barbano, 2013). As a result, the shelf-life of $\mathrm{CMC}$ has become an important factor for its use by the dairy industry.

Muir (1996) reported that the shelf-life of a dairy product is the time in which the product remains safe (no pathogenic bacteria) and shows no organoleptic defects (e.g., bitterness, acidic flavor). It has been reported that the shelf-life of dairy products is limited by the growth of spoilage bacteria (Muir, 1996), which produce enzymes that can degrade milk constituents and cause unacceptable quality. The end of the shelflife of CMC (18\% TP and 22\% TS) has been suggested as the point at which the total aerobic bacterial count (TBC) is $>4.3 \log \mathrm{cfu} / \mathrm{mL}$ (Amelia and Barbano, 2013), because this is the legal limit for the shelf-life of pasteurized milk based on the Pasteurized Milk Ordinance (FDA, 2009). Some additives may have an influence on the functionality as well as the shelf-life of CMC. The addition of sodium chloride to CMC could increase the shelf-life and decrease proteolysis because it is a potential preservative. Also, the addition of emulsifying salts (such as sodium citrate) increases the dispersibility and solubility of CMC (Lu et al., 2015), which could improve the functionality of process cheese products when CMC is used as an ingredient.

We hypothesize that it may be possible to use a GP $\mathrm{MF}$ system to further concentrate CMC as an alternative to vacuum evaporation ( $\mathrm{Lu}$ et al., 2015) or using multiple filtration systems (Amelia and Barbano, 2013). Consequently, there is a possibility of producing CMC with $>25 \%$ TS using only a GP MF system. The objectives of this research were to develop a process to manufacture $\mathrm{CMC}[>25 \%$ TS and $95 \% \mathrm{CN}$ as a percentage of TP (CN\% TP)] using a GP ceramic MF system and to evaluate the effect of sodium chloride and sodium citrate on its storage stability during $60 \mathrm{~d}$ of storage at $4^{\circ} \mathrm{C}$.

\section{MATERIALS AND METHODS}

\section{Experimental Design}

The manufacture of CMC was completed over a period of $2 \mathrm{~d}$ at the South Dakota State University Dairy Plant (Brookings, SD). The experiment was repeated 3 times with different lots of skim milk. Chemical and microbiological analyses were performed on CMC at 
0,30 , and $60 \mathrm{~d}$ of storage at $4^{\circ} \mathrm{C}$, to examine shelf-life stability.

\section{Preparation of Skim Milk}

Approximately $685 \mathrm{~kg}$ of whole bovine milk was separated (model MSE 140-48-177 AirTight centrifuge, GEA Co.) at $4^{\circ} \mathrm{C}$ at the South Dakota State University Dairy Plant. Subsequently, pasteurization $\left(76^{\circ} \mathrm{C} / 16 \mathrm{~s}\right)$ was applied to the skim milk in a plate heat exchanger (model PR02-SH, AGC Engineering). The pasteurized skim milk was then kept at $\leq 4^{\circ} \mathrm{C}$ until MF was conducted the following day. Tanks and milk cans were covered during processing to minimize airborne contamination from the plant environment.

\section{Microfiltration Operation and CMC Manufacturing}

To produce CMC, a pilot-scale ceramic GP MF system (TIA) was used. This GP MF system was equipped with 7 ceramic tubes (19 channels with a diameter of $3.3 \mathrm{~mm}$ each) mounted in the system vertically. The ceramic Membralox GP membranes had a $0.1-\mu \mathrm{m}$ pore size, $1.68-\mathrm{m}^{2}$ surface area, and 1.02-m membrane length. The GP MF system was also equipped with a feed pump and a retentate recirculation pump (TIA).

First Stage: Day 1. The GP MF system was started with soft water at $50^{\circ} \mathrm{C}$; subsequently, the system was transitioned from water to milk. Approximately $670 \mathrm{~kg}$ of skim milk was MF with the GP MF system at a constant flux $\left(71.42 \mathrm{~L} / \mathrm{m}^{2}\right.$ per hour) using a $3 \times \mathrm{CF}(1$ $\mathrm{kg}$ of retentate to $2 \mathrm{~kg}$ of permeate) in a feed-and-bleed mode at $50^{\circ} \mathrm{C}$ (Figure 1). The skim milk was heated to $50^{\circ} \mathrm{C}$ with a heat plate exchanger (SABCO PlatePro Sanitary Chiller, NP925-41) before processing. The water at the beginning of the process was flushed out with skim milk by collecting about $37 \mathrm{~kg}$ of permeate and $18 \mathrm{~kg}$ of retentate in cans that were discarded. The permeate flow rate was $120 \mathrm{~L} / \mathrm{h}$ (flux of $71.42 \mathrm{~L} / \mathrm{m}^{2}$ per hour), and the retentate flow rate was $60 \mathrm{~L} / \mathrm{h}$, to produce a $3 \times$ retentate. After this startup, retentate and permeate were collected and weighed continuously. The following conditions were applied during MF of skim milk: retentate pressure inlet $(\mathbf{R p i})$, retentate pressure outlet (Rpo), and permeate pressure outlet (Ppo) were $400,198.5$, and $186.5 \mathrm{kPa}$, respectively. The CF was measured every $15 \mathrm{~min}$ by collecting permeate and retentate samples. The composition of retentate and permeate during MF was monitored using an infrared spectrophotometer (MilkoScan FT1-Lactoscope FTIR, FOSS Instruments-FOSS Analytical A/S). During the MF process, the collected retentate was kept in tanks at $4^{\circ} \mathrm{C}$. At the end of the run, the retentate and permeate were sampled for compositional analysis. The processing time of the first stage was approximately $4 \mathrm{~h}$.

Second Stage: Day 1. The retentate from the first stage was diluted with soft water (approximately $204 \mathrm{~kg}$ of retentate was mixed with $408 \mathrm{~kg}$ of water) to obtain a DF of $3 \times$ to reach the original volume of skim milk. After mixing, the diluted retentate was heated to $50^{\circ} \mathrm{C}$ and processed with the GP MF system using a $3 \times \mathrm{CF}$, as described previously. The water at the beginning of the process was flushed out of the system with the diluted retentate as described in the first stage. The Rpi, Rpo, and Ppo were 400, 197, and $205 \mathrm{kPa}$, respectively. Permeate and retentate were weighed and sampled, as described in the first stage. The retentate was collected in sanitized cans, cooled to $4^{\circ} \mathrm{C}$, and stored overnight at $\leq 4^{\circ} \mathrm{C}$. The processing time of the second stage was approximately $3.5 \mathrm{~h}$.

Third Stage: Day 2. The following day, about 154 $\mathrm{kg}$ of the retentate $(9.65 \%$ TS and approximately $92 \%$ $\mathrm{CN} \% \mathrm{TP}$ ) was MF in a recirculation mode to produce CMC. As soon as MF was started, the retentate was further heated to $63^{\circ} \mathrm{C}$ to reduce the viscosity while minimizing denaturation of whey protein. The following conditions were applied: Rpi, Rpo, and Ppo were 398,199 , and $200 \mathrm{kPa}$, respectively, the permeate flow rate was $120 \mathrm{~L} / \mathrm{h}$ (flux of $71.42 \mathrm{~L} / \mathrm{m}^{2}$ per hour), and the retentate flow rate was $60 \mathrm{~L} / \mathrm{h}$. When the TS reached approximately $22 \%$ (as measured using CEM Smart System5 SL7199), the temperature was increased to $74^{\circ} \mathrm{C}$ to maximize the final TS content that could be obtained. Increasing the solids content of CMC during $\mathrm{MF}$ led to decreasing the Ppo until it reached $0 \mathrm{kPa}$. The decrease of Ppo is related to the concentration polarization and membrane fouling that accumulated on the membrane during recirculation of the retentate. The process was stopped when the permeate flux reached approximately $3 \mathrm{~L} / \mathrm{m}^{2}$ per hour and Ppo reached $0 \mathrm{kPa}$. The retentate from the third stage (approximately 30 $\mathrm{kg}$ ) was collected and sampled. A composite sample of the permeate was sampled for compositional analysis. The processing time for the third stage was around 2 $\mathrm{h}$. The retentate of the third stage was divided into 3 aliquots of approximately $10 \mathrm{~kg}$ each. The first portion was used as a control; $1 \%$ of sodium chloride was added into the second portion (T1), and 1\% sodium chloride $+1 \%$ sodium citrate was added to the third portion (T2). The CMC treatments were sampled at $74^{\circ} \mathrm{C}$ and transferred to $45-\mathrm{mL}$ sterilized vials (model 3040-00, Thermo Scientific-Capitol Vial Inc.) and stored at $4^{\circ} \mathrm{C}$ to evaluate the storage stability of CMC. This trial was replicated 3 times using 3 separate lots of raw milk.

Cleaning After Processing. After processing, the GP MF system was flushed with soft water to remove 
all retentate residues from the system. The initial flux was measured with approximately $60 \mathrm{~kg}$ of soft water at $27^{\circ} \mathrm{C}$. During the flux measurement the retentate valves were closed and the permeate valves were completely opened, with the feed pump running. Subsequently, 30 $\mathrm{kg}$ of soft water was added to the system and heated to $74^{\circ} \mathrm{C}$; then $900 \mathrm{~mL}$ of Ultrasil 110 Alkaline cleaner (Ecolab Inc.) and $200 \mathrm{~mL}$ of XY 12 (Ecolab Inc.) were added to get a $\mathrm{pH}$ of 11 . This solution was recirculated for $30 \mathrm{~min}$ at a $350 \mathrm{~L} / \mathrm{h}$ permeate flow rate (flux of 208 $\mathrm{L} / \mathrm{m}^{2}$ per hour). After cleaning the MF system with the alkaline solution, the membrane was cooled to $50^{\circ} \mathrm{C}$ (less than $10^{\circ} \mathrm{C}$ per min). The alkaline solution was flushed out of the MF system with soft water until the $\mathrm{pH}$ of outlet water ranged from 8.3 to 8.5. The flux was measured again, as described previously. The system was cleaned with an acid solution (Ultrasil 78 acid cleaner, Ecolab Inc.) by adding $30 \mathrm{~kg}$ of soft water and heated to $52^{\circ} \mathrm{C}$; subsequently, $400 \mathrm{~mL}$ of Ultrasil 78 (Ecolab Inc.) was added to obtain a $\mathrm{pH}$ of 2 . The recirculation of the acid solution was applied for 20 min at a flux of $208 \mathrm{~L} / \mathrm{m}^{2}$ per hour. Subsequently, the machine was stopped and the acid was retained inside the system. Before using the system again, the acid solution was flushed out with soft water until the $\mathrm{pH}$ reached 8.3 to 8.5 . The flux was measured again after flushing the acid solution.

\section{Chemical Analyses}

Skim milk, permeate, and retentate samples collected during the process were analyzed using an infrared spectrophotometer to check if the system was running normally. Ash (AOAC International, 2000, section 33.2.10, method 945.46), TS (AOAC International, 2000, section 33.2.44, method 990.20), total nitrogen (TN; AOAC International, 2000, section 33.2.11, method 991.20), NPN (AOAC International, 2000, section 33.2.12, method 991.21), and noncasein nitrogen (NCN; Zhang and Metzger, 2011) were determined in skim milk, retentate, and permeate samples for each stage and during the shelf-life of CMC. The NCN was subtracted from TN and multiplied by 6.38 to calculate CN content; NPN was subtracted from TN and
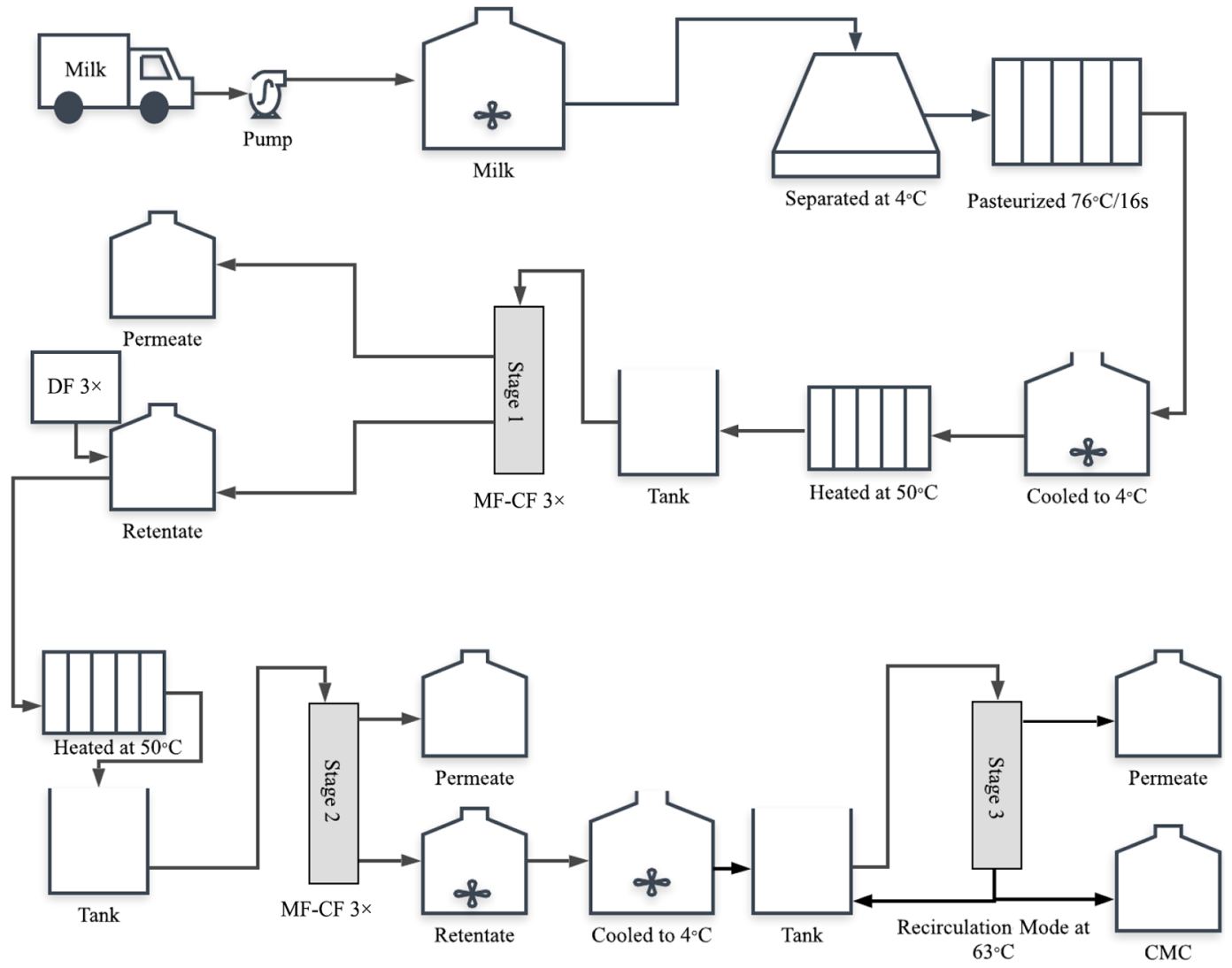

Figure 1. Schematic process diagram for manufacturing of concentrated micellar casein $(\mathrm{CMC})$ using microfiltration $(\mathrm{MF})$ : $\mathrm{CF}=$ concentration factor; $\mathrm{DF}=$ diafiltration. 
multiplied by 6.38 to calculate TP content; and NPN was subtracted from NCN and multiplied by 6.38 to calculate SP content.

\section{SP Removal}

A mass balance was conducted to determine the efficiency of SP removal from skim milk. The mass of SP in permeate was divided by the mass of SP in the skim milk and multiplied by 100 to calculate the percentage of SP removal at a given stage in the MF process. The mass of SP in permeate was calculated by multiplying the weight of removed permeate by the percentage of $\mathrm{SP}$ in this permeate, and the total mass of SP present in skim milk was calculated by multiplying the weight of skim milk by the percentage of SP in the skim milk.

\section{Capillary Gel Electrophoresis}

The protein fractions in the skim milk, permeate, and CMC were determined using capillary gel electrophoresis (CGE). Samples were diluted to $<1 \%$ protein with distilled water. Subsequently, $10 \mu \mathrm{L}$ of each diluted sample, $85 \mu \mathrm{L}$ of sample buffer (ProteomeLab SDS-MW Analyses Kit, Beckman-Coulter), and $5 \mu \mathrm{L}$ of $\beta$-mercaptoethanol were pipetted into a PCR vial (Fisher Scientific) and heated in a water bath at $90^{\circ} \mathrm{C}$ for $15 \mathrm{~min}$. The samples were analyzed via CGE (P/ ACE MIDQ, Beckman-Coulter) equipped with a UV detector set at $214 \mathrm{~nm}$. The test was performed using a $50-\mu \mathrm{m}$ bare fused silica capillary $(20.2-\mathrm{cm}$ effective length from the inlet to the detection window). Solution and reagents were obtained as a part of the ProteomeLab SDS-Molecular Weight Analysis Kit (Beckman-Coulter), which is designed for separation of protein SDS complexes, using a replaceable gel matrix. The gel is formulated to provide an effective sieving range of approximately 10 to $225 \mathrm{kDa}$. An SDS-molecular weight (MW) size standard (recombinant proteins 10-225 kDa supplied with the ProteomeLab SDS-MW Analysis Kit) was used to estimate MW of the proteins in each sample. A capillary preconditioning method (basic rinse-0.1 $N$ NaOH-5 min-50 psi, acidic rinse-0.1 $N$ HCl-2 min-50 psi, distilled water rinse-2 min-50 psi, and SDS gel rinse-10 min-40 psi) was run every 3 samples, and then the sample was electrokinetically introduced at $5 \mathrm{kV}$ for $20 \mathrm{~s}$. Separation was performed using the following conditions: a constant voltage of 15 $\mathrm{kV}$, temperature $25^{\circ} \mathrm{C}$, and 20 bar pressure with reverse polarity in the SDS-MW gel buffer. The MW standards (ProteomeLab and Beckman-Coulter) and available pure milk protein fractions (Sigma) were also separated using the method described earlier to calculate migration times.
The migration time of the peaks resulting from the capillary electropherogram was compared with MW standards and pure standard samples to identify the peaks. Also, the peaks were compared with results reported by other researchers (Creamer and Richardson, 1984; Miralles et al., 2000, 2003; Anema, 2009; Salunke, 2013). The area of each identified peak was calculated from the electropherogram using a valley-to-valley approach, as described by Miralles et al. (2003). The areas of each identified individual $\mathrm{CN}$ fraction (such as $\alpha \mathrm{S}_{1}$, $\alpha \mathrm{S}_{2}, \beta, \kappa$, and $\gamma-\mathrm{CN}$ ), SP fractions (such as $\alpha-\mathrm{LA}$ and $\beta-\mathrm{LG}$ ), and peptides (peaks between 10 and $20 \mathrm{kDa}$ ) were calculated as percentage of total area (positive peaks).

\section{Microbiological Analyses}

All CMC treatments were analyzed for TBC, coliforms, yeast, and mold at 0,30 , and $60 \mathrm{~d}$ of storage at $4^{\circ} \mathrm{C}$. The TBC (method 6.040, Wehr and Frank, 2004), coliform count (method 7.074, Wehr and Frank, 2004), and yeast and mold counts (method 8.115, Wehr and Frank, 2004) were determined during the shelf-life. Petrifilms (3M) were used for the TBC, coliform count, and yeast and mold counts. A sterile phosphate buffer was used for dilutions (Weber Scientific). The TBC Petrifilms were incubated at $32 \pm 1^{\circ} \mathrm{C}$ for $48 \mathrm{~h} \pm 3 \mathrm{~h}$; coliform Petrifilm plates were incubated at $32^{\circ} \mathrm{C} \pm 1^{\circ} \mathrm{C}$ for $24 \mathrm{~h} \pm 2 \mathrm{~h}$; and yeast and mold Petrifilm plates were incubated at $25^{\circ} \mathrm{C} \pm 1{ }^{\circ} \mathrm{C}$ for $5 \mathrm{~d}$. All Petrifilms were counted and rounded, as described by Wehr and Frank (2004).

\section{Shelf-Life Study}

Samples were analyzed chemically (ash, TN, NCN, NPN, TS, and CGE) and microbiologically (TBC, coliform count, and yeast and mold counts) at 0,30 , and $60 \mathrm{~d}$ of storage. The end of shelf-life was defined as TBC $>20,000 \mathrm{cfu} / \mathrm{mL}(>4.3 \log \mathrm{cfu} / \mathrm{mL})$, as described by Amelia and Barbano (2013).

\section{Statistical Analyses}

Processing data were analyzed using $\mathrm{R}$ software ( $\mathrm{R}$ $\times 64-3.3 .3$, R Foundation for Statistical Computing) to determine the differences among means of the $3 \mathrm{MF}$ stages. Statistical analysis was also performed to study the effects of treatment and storage time, and the interaction of these factors on the shelf-stability of CMC. An ANOVA was performed to obtain the mean squares and $P$-values, using the GLM procedure available in $\mathrm{R}$ software. When a significant treatment, time, or interaction effect $(P<0.05)$ was detected, differences 
Table 1. Mean ( $\mathrm{n}=3)$ composition (\% by weight) of the pasteurized skim milk

\begin{tabular}{|c|c|c|c|c|c|c|c|c|c|}
\hline Replicate & \multicolumn{9}{|c|}{ Composition $^{1}$} \\
\hline 1 & 8.79 & 3.10 & 0.64 & 0.20 & 2.46 & 0.44 & 0.74 & 79.23 & 84.78 \\
\hline 3 & 9.04 & 3.26 & 0.66 & 0.17 & 2.60 & 0.49 & 0.67 & 79.57 & 84.15 \\
\hline Mean & 8.92 & 3.28 & 0.66 & 0.19 & 2.62 & 0.47 & 0.69 & 79.75 & 84.66 \\
\hline SD & 0.12 & 0.19 & 0.02 & 0.01 & 0.17 & 0.03 & 0.04 & 0.62 & 0.028 \\
\hline
\end{tabular}

${ }^{1} \mathrm{TN}=$ total nitrogen $\times 6.38 ; \mathrm{NCN}=$ noncasein nitrogen $\times 6.38 ; \mathrm{NPN}=$ nonprotein nitrogen $\times 6.38 ; \mathrm{CN}=\mathrm{TN}-\mathrm{NCN} ; \mathrm{SP}=$ serum protein: $\mathrm{NCN}-\mathrm{NPN} ; \mathrm{CN} \% \mathrm{TN}=\mathrm{CN}$ as a percentage of $\mathrm{TN} ; \mathrm{CN} \% \mathrm{TP}=\mathrm{CN}$ as a percentage of $\mathrm{TP}$

among means were compared using the least significant difference test.

\section{RESULTS AND DISCUSSION}

\section{Composition of Skim Milk}

The composition of pasteurized skim milk used to produce CMC is shown in Table 1 . We found a small amount of variation $(0.12,0.19,0.02,0.01,0.17,0.03$, and $0.04 \%$ SD for the TS, TN, NCN, NPN, CN, SP, and ash contents, respectively), among the 3 replicates. The $\mathrm{CN}$ as a percentage of TN (CN\% $\mathbf{T N})$ and the CN\%TP were typical (Beckman et al., 2010; Hurt and Barbano, 2010; Adams and Barbano, 2013) and ranged from 79.23 to $80.45 \%$ for CN\% TN and from 84.15 to $85.06 \%$ for CN\%TP. The skim milk was pasteurized at $76^{\circ} \mathrm{C}$ for $16 \mathrm{~s}$. Temperatures over $70^{\circ} \mathrm{C}$ can lead to interactions between $\beta-\mathrm{LG}$ and $\kappa-\mathrm{CN}$ through disulfide bonding (Singh, 1995; Hammam et al., 2021). Consequently, an elevated pasteurization temperature can decrease the SP available for removal during MF (Hurt and Barbano, 2010; Hammam et al., 2021).

\section{Composition of Permeate}

The composition of permeate from each stage of MF is presented in Table 2. The TS, TN, NPN, and SP contents of the permeate significantly decreased $(P<$ $0.05)$ with each subsequent stage of MF. The SP concentrations in the permeate were $0.33,0.26$, and $0.15 \%$ for the first, second, and third stages, respectively, using $3 \times \mathrm{CF}$ in the first and second stages and approximately $5 \times$ in the third stage, with 1 DF stage applied to the retentate of the first stage. The SP content in the first-stage permeate $(0.33 \%)$ was lower than $\mathrm{SP}$ in the permeate portion of the pasteurized skim milk (0.47\%). This was primarily due to some rejection of SP by the membrane. Similar results have been reported by Tremblay-Marchand et al. (2016) using a 0.1- $\mu \mathrm{m}$ GP ceramic membrane and 3 stages of $3 \times \mathrm{CF}$ with $\mathrm{DF}$. That study found that permeate of the first, second, and third stages contained $0.35,0.13$, and $0.06 \% \mathrm{SP}$, respectively, from MF of skim milk that contained $0.49 \%$ SP. However, another study found that permeate of the first, second, and third stages produced from a $0.1-\mu \mathrm{m}$ GP membrane using 3 stages of $3 \times \mathrm{CF}$ with DF contained $0.51,0.25$, and $0.13 \%$ of SP, respectively, from MF of skim milk that had $0.54 \%$ SP (Zulewska and Barbano, 2014). The processing conditions, such as pasteurization temperature could affect SP removal in the permeate of the first stage, due to the denaturation of SP on CN. However, the SP removal in the second and third stages was similar to our study. Although the third stage of our study was processed in a recirculation mode using $5 \times \mathrm{CF}$ without $\mathrm{DF}$, to increase the solids, the SP removed in the permeate of this stage was similar to the typical feed-and-bleed mode using $3 \times$ CF with DF (Zulewska and Barbano, 2014), and this can be related to that the majority of SP being removed during the first and second stages of MF. The ash content decreased significantly $(P<0.05)$ between the first and second stages; however, the ash content in the third stage was not significantly different $(P>$ $0.05)$ from the second stage. This is due to the majority of the remaining ash content after the second stage being bound within the $\mathrm{CN}$ micelle, which is rejected by the membrane.

Table 2. Mean ( $\mathrm{n}=3$ ) composition (\% by weight) of permeates produced from the 3 stages of microfiltration (MF) using $0.1-\mu \mathrm{m}$ ceramic graded permeability membranes

\begin{tabular}{lccccc}
\hline & \multicolumn{5}{c}{ Composition $^{1}$} \\
\cline { 2 - 6 } MF stage & TS & TN & NPN & SP & Ash \\
\hline 1 & $6.00^{\mathrm{a}}$ & $0.52^{\mathrm{a}}$ & $0.19^{\mathrm{a}}$ & $0.33^{\mathrm{a}}$ & $0.47^{\mathrm{a}}$ \\
2 & $2.02^{\mathrm{b}}$ & $0.35^{\mathrm{b}}$ & $0.08^{\mathrm{b}}$ & $0.26^{\mathrm{b}}$ & $0.18^{\mathrm{b}}$ \\
3 & $1.60^{\mathrm{c}}$ & $0.20^{\mathrm{c}}$ & $0.05^{\mathrm{c}}$ & $0.15^{\mathrm{c}}$ & $0.12^{\mathrm{b}}$ \\
SEM & 0.70 & 0.05 & 0.02 & 0.03 & 0.05 \\
$\mathrm{R}^{2}$ & 0.99 & 0.95 & 0.97 & 0.89 & 0.93 \\
\hline
\end{tabular}

${ }^{\mathrm{a}-\mathrm{c}}$ Means in the same column not sharing a common superscript are different $(P<0.05)$.

${ }^{1} \mathrm{TN}=$ total nitrogen $\times 6.38 ; \mathrm{NPN}=$ nonprotein nitrogen $\times 6.3 ; \mathrm{SP}=$ serum protein: TN - NPN. 
Table 3. Mean $(\mathrm{n}=3)$ composition (\% by weight) of retentates produced from the 3 stages of microfiltration (MF) using $0.1-\mu \mathrm{m}$ ceramic graded permeability membranes

\begin{tabular}{|c|c|c|c|c|c|c|c|c|c|c|}
\hline \multirow{2}{*}{$\begin{array}{l}\text { MF } \\
\text { stage }\end{array}$} & \multicolumn{10}{|c|}{ Composition $^{1}$} \\
\hline & TS & $\mathrm{TN}$ & $\mathrm{NCN}$ & $\mathrm{NPN}$ & $\mathrm{TP}$ & $\mathrm{CN}$ & $\mathrm{SP}$ & Ash & CN\%TP & TN\%TS \\
\hline 1 & $14.11^{\mathrm{b}}$ & $8.14^{\mathrm{b}}$ & $1.06^{\mathrm{a}}$ & $0.21^{\mathrm{a}}$ & $7.92^{\mathrm{b}}$ & $7.07^{\mathrm{b}}$ & $0.85^{\mathrm{a}}$ & $1.11^{\mathrm{b}}$ & $89.23^{\mathrm{c}}$ & $57.75^{\mathrm{c}}$ \\
\hline 2 & $9.64^{\mathrm{c}}$ & $7.05^{\mathrm{b}}$ & $0.66^{\mathrm{b}}$ & $0.09^{\mathrm{b}}$ & $6.96^{\mathrm{b}}$ & $6.38^{\mathrm{b}}$ & $0.58^{\mathrm{b}}$ & $0.78^{\mathrm{c}}$ & $91.65^{\mathrm{b}}$ & $73.21^{\mathrm{b}}$ \\
\hline 3 & $25.41^{\mathrm{a}}$ & $21.75^{\mathrm{a}}$ & $0.55^{\mathrm{c}}$ & $0.09^{\mathrm{b}}$ & $21.65^{\mathrm{a}}$ & $21.20^{\mathrm{a}}$ & $0.45^{\mathrm{c}}$ & $2.00^{\mathrm{a}}$ & $97.92^{\mathrm{a}}$ & $85.59^{\mathrm{a}}$ \\
\hline SEM & 2.00 & 1.93 & 0.060 & 0.017 & 1.94 & 1.95 & 0.05 & 0.15 & 1.43 & 5.05 \\
\hline $\mathrm{R}^{2}$ & 0.98 & 0.99 & 0.96 & 0.93 & 0.99 & 0.99 & 0.93 & 0.98 & 0.98 & 0.98 \\
\hline
\end{tabular}

${ }^{\mathrm{a}-\mathrm{c}}$ Means in the same column not sharing a common superscript are different $(P<0.05)$.

${ }^{1} \mathrm{TN}=$ total nitrogen $\times 6.38 ; \mathrm{NCN}=$ noncasein nitrogen $\times 6.38 ; \mathrm{NPN}=$ nonprotein nitrogen $\times 6.38 ; \mathrm{TP}=$ true protein: $\mathrm{TN}-\mathrm{NPN} ; \mathrm{CN}=$ $\mathrm{TN}-\mathrm{NCN} ; \mathrm{SP}=$ serum protein: $\mathrm{NCN}-\mathrm{NPN} ; \mathrm{CN} \% \mathrm{TP}=\mathrm{CN}$ as a percentage of TP; TN\% TS $=$ TN as a percentage of TS.

\section{Composition of Retentate}

The composition of the retentate from the $3 \mathrm{MF}$ stages is shown in Table 3. The TS and TN content decreased between stage 1 and stage 2 due to the passage of soluble minerals, lactose, and SP through the membrane. The composition of the first and second stages of MF retentate in our study was similar to the typical composition of retentate produced from those 2 stages using a $3 \times \mathrm{CF}$ with DF (Beckman et al., 2010; Zulewska and Barbano, 2014; Tremblay-Marchand et al., 2016). The composition of retentate produced from MF of skim milk can be slightly different based on the composition of initial milk and processing conditions. The TS, TN, TP, CN, and ash values of the retentate were significantly higher $(P<0.05)$ in the third stage compared with the first and second stages, due to the rejection of $\mathrm{CN}$ by the membrane. Because two-thirds of the ash is bound to the CN (Hurt and Barbano, 2010), the ash content in the third stage increased with increasing $\mathrm{CN}$ content. The SP content in the retentate decreased $(P<0.05)$ with each successive stage of MF due to passage through the membrane into the permeate. As expected, the $\mathrm{CN} \% \mathrm{TP}$ and $\mathrm{TN}$ as a percentage of TS (TN\%TS) increased significantly $(P<0.05)$ with each subsequent stage of MF. The CN\%TP increased from $84.66 \%$ in the skim milk to approximately $98 \%$ in the final CMC product.

\section{SP Removal}

Theoretical SP removal, actual SP removal, and CF of 3 MF stages are presented in Table 4. Theoretically, the cumulative SP removal from skim milk should be $67.8,89.8$, and $97.8 \%$ in the first, second, and third stages, respectively. The actual SP removal in our study was $46.20,77.20$, and $83.10 \%$ in the first, second, and third stages, respectively. It was expected that the theoretical SP removal would be higher than the actual SP removal from skim milk, because the theory of SP removal assumes that the membrane does not reject $\mathrm{SP}$, but in reality some SP is rejected by the membrane. Hurt and Barbano (2010) reported percentages of cumulative SP removal from MF of skim milk (CN\% TP $=85.00 \%)$ as approximately 56,74 , and $80 \%$ in the first, second, and third stages, respectively, using $3 \times$ $\mathrm{CF}$ with DF water within stages, which was close to our values. Another study has reported that SP removal in the first, second, and third stages was 47.0, 64.7, and $73.2 \%$, respectively, using GP MF system (TremblayMarchand et al., 2016). The slight difference in SP removal between our study and others can be related to the initial milk composition and processing conditions, which can reflect on SP removal in the first, second, and third stages of MF. However, Tremblay-Marchand et al. (2016) have reported that the calculation of SP removal based on the mass balance might not be accurate because it does not take into consideration the remaining $\mathrm{SP}$ in the retentate.

Table 4. Mean $(\mathrm{n}=3)$ serum protein $(\mathrm{SP})$ removal for the 3 stages of microfiltration (MF) using $0.1-\mu \mathrm{m}$ ceramic graded permeability membranes, determined by Kjeldahl analysis and concentration factor (CF)

\begin{tabular}{lccc}
\hline $\begin{array}{l}\text { MF } \\
\text { stage }\end{array}$ & $\begin{array}{c}\text { Theoretical SP } \\
\text { removal }^{1}(\%)\end{array}$ & $\begin{array}{c}\text { Actual SP } \\
\text { removal (\%) }\end{array}$ & $\mathrm{CF}^{2}$ \\
\hline 1 & 67.78 & $46.20^{\mathrm{c}}$ & $3.01^{\mathrm{b}}$ \\
2 & 89.78 & $77.20^{\mathrm{b}}$ & $3.01^{\mathrm{b}}$ \\
3 & 97.78 & $83.10^{\mathrm{a}}$ & $5.12^{\mathrm{a}}$ \\
SEM & & 5.75 & 0.41 \\
$\mathrm{R}^{2}$ & & 0.98 & 0.71 \\
\hline
\end{tabular}

$\overline{{ }^{a c} \text { Means in the same column not sharing a common superscript are }}$ different $(P<0.05)$.

${ }^{1}$ Data in this column represent theoretical SP removal, assuming no rejection of serum proteins and complete rejection of $\mathrm{CN}$ :

$\%$ SP removal of each stage

$=\left(\frac{\% \mathrm{SP} \text { in permeate of each stage } \times \text { amount of permeate }}{\% \text { SP in feed } \times \text { amount of feed }}\right) \times 100$.

${ }^{2} \mathrm{CF}=$ concentration factor. 
Table 5. Mean $(\mathrm{n}=3)$ composition (\% by weight) of the concentrated micellar casein $(\mathrm{CMC})$, measured after manufacturing $(\mathrm{d}=0)$

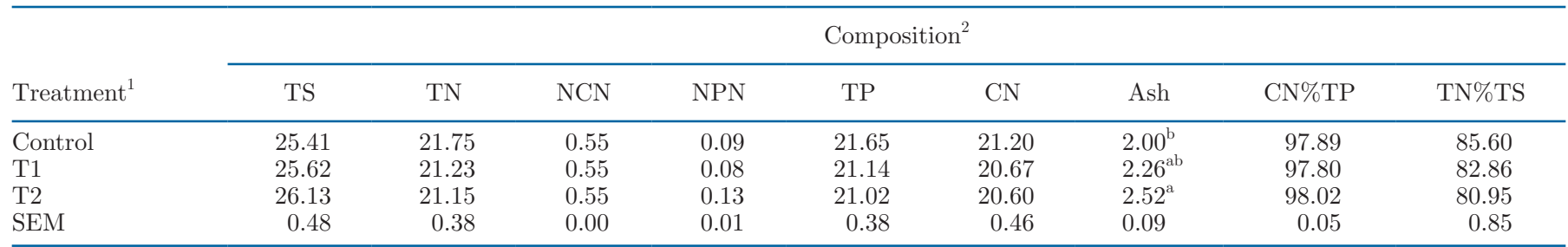

${ }^{\mathrm{a}, \mathrm{b}}$ Means in the same column not sharing a common superscript are different $(P<0.05)$.

${ }^{1}$ Control $=\mathrm{CMC} ; \mathrm{T} 1=\mathrm{CMC}+1 \%$ sodium chloride; $\mathrm{T} 2=\mathrm{CMC}+1 \%$ sodium chloride and $1 \%$ sodium citrate.

${ }^{2} \mathrm{TN}=$ total nitrogen $\times 6.38 ; \mathrm{NCN}=$ noncasein nitrogen $\times 6.38 ; \mathrm{NPN}=$ nonprotein nitrogen $\times 6.38 ; \mathrm{TP}=$ true protein: $\mathrm{TN}-\mathrm{NPN} ; \mathrm{CN}=$ $\mathrm{TN}-\mathrm{NCN} ; \mathrm{CN} \% \mathrm{TP}=\mathrm{CN}$ as a percentage of $\mathrm{TP} ; \mathrm{TN} \% \mathrm{TS}=\mathrm{TN}$ as a percentage of $\mathrm{TS}$.

The $\mathrm{CF}$ is the ratio of feed mass for each stage to the retentate mass of the same stage. In practice, the ability of the system to control the CF precisely may vary and may be limited, but the CF was close to the targeted values of $3 \times$ in the first and second stages and $5 \times$ for the third stage.

\section{Composition of CMC}

The composition of CMC after manufacturing is exemplified in Table 5. The addition of sodium chloride or sodium citrate to $\mathrm{CMC}$ did not result in significant differences $(P>0.05)$ in the TS, TN, NCN, NPN, TP, $\mathrm{CN}, \mathrm{CN} \% \mathrm{TP}$, and TN\%TS after processing (Table 5 ). However, we found a significant difference $(P<0.05)$ in the ash content between control and T2. This was expected due to the addition of sodium chloride and sodium citrate to $\mathrm{T} 2$. The addition of $1 \%$ sodium chloride in $\mathrm{T} 1$ and $1 \%$ sodium chloride $+1 \%$ sodium citrate in $\mathrm{T} 2$ was expected to increase the TS content by $1 \%$ and $2 \%$ in $\mathrm{T} 1$ and $\mathrm{T} 2$, respectively, relative to the control. The ash content should also be higher in $\mathrm{T} 1$ and $\mathrm{T} 2$ by $1 \%$ and $2 \%$, respectively, compared with control. However, the TS and ash contents were not as high as expected in $\mathrm{T} 1$ and $\mathrm{T} 2$ compared with the control. We theorized that this could occur because those salts were added and mixed manually in the $\mathrm{CMC}$, and this may not have evenly dispersed the salts when samples were collected.

The NCN and NPN contents of CMC at 0 and 60 $\mathrm{d}$ of storage are shown in Table 6, and the ANOVA with mean squares and $P$-values for NCN and NPN during shelf-life are shown in Table 7 . The NCN and NPN of the CMC were monitored for $60 \mathrm{~d}$ to determine the level of proteolysis (Table 6). No significant difference $(P>0.05)$ was found between treatments in the NPN or NCN content at $0 \mathrm{~d}$. However, a significant difference $(P<0.05)$ was observed in the NCN content during $60 \mathrm{~d}$ of storage at $4^{\circ} \mathrm{C}$ (Table 7 ). The increase in NCN could be a result of the degradation of $\beta-C N$ by proteolytic enzymes, such as plasmin, which produces $\gamma$-CN and small peptides.

\section{Microbiological Analysis of CMC}

The TBC $(\log \mathrm{cfu} / \mathrm{mL})$ of CMC treatments during storage is shown in Table 8 , and the mean squares and $P$-values for the TBC are presented in Table 9. The mean TBC of the CMC at d 0 (immediately after manufacturing) were $2.6,2.5$, and $2.8 \log \mathrm{cfu} / \mathrm{mL}$ for control, $\mathrm{T} 1$, and $\mathrm{T} 2$, respectively (Table 8 ). This was slightly different from the $2.1 \log \mathrm{cfu} / \mathrm{mL}$ in pasteurized $\mathrm{CMC}$

Table 6. Mean $(\mathrm{n}=3)$ noncasein nitrogen $(\mathrm{NCN})$ and NPN of the concentrated micellar casein $(\mathrm{CMC})$ measured over $60 \mathrm{~d}$ of storage at $4^{\circ} \mathrm{C}$

\begin{tabular}{lccccc}
\hline & & \multicolumn{3}{c}{ Treatment $^{2}$} \\
\cline { 3 - 5 } Composition $^{1}$ & Time & Control & T1 & \multirow{2}{*}{ T2 } & Mean \\
\hline NCN & 0 & 0.55 & 0.55 & 0.55 & $0.55^{\mathrm{b}}$ \\
& 60 & 0.76 & 0.82 & 0.94 & $0.84^{\mathrm{a}}$ \\
NPN & Mean & 0.66 & 0.68 & 0.74 & 0.10 \\
& 0 & 0.09 & 0.08 & 0.13 & 0.13 \\
& 60 & 0.12 & 0.13 & 0.14 & 0.14 \\
\end{tabular}

a,b Means in the same column not sharing a common superscript are different $(P<0.05)$.

${ }^{1} \mathrm{NCN}=$ noncasein nitrogen $\times 6.38 ; \mathrm{NPN}=$ nonprotein nitrogen $\times 6.38$.

${ }^{2} \mathrm{Control}=\mathrm{CMC} ; \mathrm{T} 1=\mathrm{CMC}+1 \%$ sodium chloride; $\mathrm{T} 2=\mathrm{CMC}+1 \%$ sodium chloride and $1 \%$ sodium citrate. 
Table 7. Mean squares and $P$-values (in parentheses) of the noncasein nitrogen (NCN) and NPN for the concentrated micellar casein $(\mathrm{CMC})$ measured over $60 \mathrm{~d}$ of storage at $4^{\circ} \mathrm{C}$

\begin{tabular}{lccc}
\hline Factor & df & NCN & NPN \\
\hline Replication & 2 & $0.021(0.26)$ & $0.0099(<0.05)$ \\
Treatment $^{1}$ & 2 & $0.012(0.22)$ & $0.0012(0.51)$ \\
Time $^{2}$ & 1 & $0.38(<0.05)$ & $0.0035(0.18)$ \\
Treatment $\times$ time & 2 & $0.012(0.23)$ & $0.0009(0.61)$ \\
Error & 10 & 0.007 & 0.001 \\
${ }^{1}$ Control $=$ CMC; T1 $=$ CMC + 1\% sodium chloride; T2 & $=$ CMC $+1 \%$ sodium chloride and $1 \%$ sodium citrate. \\
${ }^{2}$ Time $=0$ and 60 d of storage. &
\end{tabular}

(18\% TP and $22 \%$ TS) at $\mathrm{d} 0$ reported by Amelia and Barbano (2013). All tanks and cans were covered during the experiment to reduce environmental contamination. The addition of sodium chloride or sodium citrate to $\mathrm{CMC}$ did not result in significant differences $(P>$ $0.05)$ in the TBC (Table 9). The mean TBC increased significantly $(P<0.05)$ in all treatments during $60 \mathrm{~d}$ of storage at $4^{\circ} \mathrm{C}$. Amelia and Barbano (2013) defined the end of the shelf-life when the TBC is $>4.3 \log \mathrm{cfu} / \mathrm{mL}$, which is the legal limit for the shelf-life of pasteurized milk (FDA, 2009). As a result, the end of the shelf-life of CMC in our study is $60 \mathrm{~d}$ when it is stored at $4^{\circ} \mathrm{C}$. Additionally, no coliforms, yeast, or mold were detected $(<1$ estimated count) at any time point during $60 \mathrm{~d}$ of storage. It has been reported that CMC $(18.27 \% \mathrm{TP}$ and $21.78 \%$ TS) could be stored for 16 wk at $4^{\circ} \mathrm{C}$ with minimal proteolysis and low bacterial count (Amelia and Barbano, 2013). That study had a longer shelf-life than our study because they used UF before starting 3 stages of MF and at the end of the process to remove as much lactose and NPN as possible, considered nutrient sources for the microbes, and this, in turn, can result in longer shelf-life.

\section{Protein Fractions}

Skim Milk and CMC Treatments. A representative CGE electrophoretogram for skim milk is shown in Figure 2. Also, representative electrophoretograms

Table 8. Mean $(\mathrm{n}=3) \log \mathrm{cfu} / \mathrm{mL}$ of total aerobic bacterial count (TBC) of the concentrated micellar casein (CMC) measured every 30 d over $60 \mathrm{~d}$ of storage at $4^{\circ} \mathrm{C}$

\begin{tabular}{lcccc}
\hline & & \multicolumn{3}{c}{ Treatment $^{1}$} \\
\cline { 3 - 5 } TBC & Time & Control & T1 & T2 \\
\hline Log cfu $/ \mathrm{mL}$ & 0 & 2.63 & 2.50 & 2.79 \\
& 30 & 3.53 & 4.04 & 4.33 \\
SEM & 60 & 4.33 & 4.06 & 5.30 \\
& & 0.45 & 0.40 & 0.46 \\
\hline
\end{tabular}

${ }^{1}$ Control $=\mathrm{CMC} ; \mathrm{T} 1=\mathrm{CMC}+1 \%$ sodium chloride; $\mathrm{T} 2=\mathrm{CMC}+$ $1 \%$ sodium chloride and $1 \%$ sodium citrate. of control, T1, and T2 CMC are presented in Figures 3,4 , and 5 , respectively. The protein fractions are migrated and separated based on their MW. Among the $\mathrm{CN}$ fractions, the $\beta$-CN peak migrated first, followed by $\alpha_{S_{1}}-\mathrm{CN}$ although the MW of $\alpha_{\mathrm{S}^{-}} \mathrm{CN}$ is lower. Other researchers have reported similar results (Creamer and Richardson, 1984; Anema, 2009; Salunke, 2013). Creamer and Richardson (1984) reported that $\alpha_{\mathrm{S} 1}-\mathrm{CN}$ has a reduced electrophoretic velocity due to its negatively charged regions, which extend its conformation in the presence of SDS, thereby giving an increased apparent size and slower migration under SDS-PAGE conditions (Creamer and Richardson, 1984; Anema, 2009). Although $\kappa-\mathrm{CN}$ has a low MW compared with other caseins, it eluted last after all other $\mathrm{CN}$ fractions. The late migration of $\kappa-\mathrm{CN}$ is attributable to the glycosylation of $\kappa-\mathrm{CN}$ (Walstra and Jenness, 1984; Anema, 2009; Salunke et al., 2011). Changes in any protein fraction, such as hydrolysis or crosslinking, that change the MW lead to changes in the peaks' heights and migration times.

The percent of protein fractions in pasteurized skim milk, control, T1, and T2 CMC measured by CGE are shown in Table 10. The percentage of peak areas in skim milk for $\beta$-CN, $\alpha_{\mathrm{S}_{1}} \mathrm{CN}, \alpha_{\mathrm{S} 2}-\mathrm{CN}, \kappa-\mathrm{CN}$, and $\gamma$-CN (CN fractions) were $33.8,35.2,8.5,4.3$, and $1.1 \%$, respectively, whereas the percentages of $\beta-\mathrm{LG}$ and $\alpha$-LA (SP fractions) obtained were 9.9 and $5.2 \%$, respectively. It has been reported that the mean $\mathrm{CN}$ fractions in

Table 9. Mean squares and $P$-values (in parentheses) of $\log \mathrm{cfu} / \mathrm{mL}$ of total aerobic bacterial count (TBC) of the concentrated micellar casein $(\mathrm{CMC})$ measured every $30 \mathrm{~d}$ over $60 \mathrm{~d}$ of storage at $4^{\circ} \mathrm{C}$

\begin{tabular}{lcc}
\hline Factor & df & TBC $(\log \mathrm{cfu} / \mathrm{mL})$ \\
\hline Replication $^{1}$ & 2 & $3.06(0.08)$ \\
Treatment $^{2}$ & 2 & $1.17(0.35)$ \\
Time $^{2}$ & 2 & $8.75(<0.05)$ \\
Treatment $\times$ time & 4 & $0.32(0.87)$ \\
Error & 16 & 1.05
\end{tabular}

${ }^{1}$ Control $=\mathrm{CMC} ; \mathrm{T} 1=\mathrm{CMC}+1 \%$ sodium chloride; $\mathrm{T} 2=\mathrm{CMC}+$ $1 \%$ sodium chloride and $1 \%$ sodium citrate.

${ }^{2}$ Time $=0,30$, and $60 \mathrm{~d}$ of storage. 
normal milk, including $\beta-\mathrm{CN}, \alpha_{\mathrm{S} 1}-\mathrm{CN}, \alpha_{\mathrm{S} 2^{-}} \mathrm{CN}, \kappa-\mathrm{CN}$, and $\gamma$-CN were approximately $33.8,34.4,8.5,8.5$, and $3.0 \%$, respectively, and means of SP fractions of $\beta-\mathrm{LG}$ and $\alpha-\mathrm{LA}$ were 9.5 and $5.1 \%$, respectively (Walstra and Jenness, 1984; Fox and McSweeney, 1998; Farrell et al., 2004), which are similar to our results. However, we noticed that the $\mathrm{k}-\mathrm{CN}$ determined by CGE is lower than we expected, and this is due to the carbohydrate moiety of $\kappa$-CN, which is difficult to detect using UV detection $(214 \mathrm{~nm})$ in CGE. The percentages of peak areas in control CMC for $\beta-\mathrm{CN}, \alpha_{\mathrm{S}^{-}} \mathrm{CN}, \alpha_{\mathrm{S}^{2}} \mathrm{CN}, \kappa-\mathrm{CN}$, and $\gamma-\mathrm{CN}$ determined by CGE were approximately 37.0, 39.1, 8.6, 4.4 , and $1.6 \%$, respectively, and the percentage of SP fractions for $\beta$-LG and $\alpha$-LA were approximately 3.7 and $3.3 \%$, respectively. The $\mathrm{CN}$ fractions of $\beta-\mathrm{CN}, \alpha_{\mathrm{S} 1^{-}}$ $\mathrm{CN}$, and $\gamma-\mathrm{CN}$ were higher $(P<0.05)$ in $\mathrm{CMC}$ than in skim milk, due to the concentration of $\mathrm{CN}$ during $\mathrm{MF}$. As presented in Table 10 and the electrophoretogram figures of skim milk and $\mathrm{CMC}$, the $\beta$-LG and $\alpha$-LA are significantly higher $(P<0.05)$ in skim milk relative to CMC. This is expected because MF permeates SP through the membrane, which results in a lower $\beta-\mathrm{LG}$ and $\alpha-\mathrm{LA}$ in the CMC. No differences in $\alpha_{\mathrm{S}^{2}} \mathrm{CN}$ and $\kappa-\mathrm{CN}(P>0.05)$ were detected between skim milk and CMC. The higher $\gamma-\mathrm{CN}$ in $\mathrm{CMC}$ compared with skim milk could be a result of proteolysis by plasmin during the $2 \mathrm{~d}$ of manufacturing. The $\mathrm{CN}$ and $\mathrm{SP}$ ratios measured using electrophoresis have been reported to range from 74 to $86 \%$ for $\mathrm{CN}$ and from 14 to $26 \%$ for SP (Walstra and Jenness, 1984; Fox and McSweeney, 1998; Farrell et al., 2004). The percentage of CN\% TP in skim milk using CGE in our study was $84.61 \%$, which is similar to the value of $84.66 \%$ determined using Kjeldahl analysis (Table 1).

No significant difference $(P>0.05)$ was detected between control, $\mathrm{T} 1$, and $\mathrm{T} 2$ in the protein fraction contents at d 0. Similar results for MCC produced using SW membranes have been reported using CGE (Salunke, 2013). In Salunke's study, $\beta-\mathrm{CN}, \alpha_{\mathrm{S} 1}-\mathrm{CN}$, $\alpha_{\mathrm{S}_{2}-} \mathrm{CN}, \kappa-\mathrm{CN}$, and $\gamma-\mathrm{CN}$ was $36.78,35.76,9.59,6.40$, and $3.72 \%$, respectively, versus $37.0,39.1,8.6,4.4$, and $1.6 \%$, respectively, in our study. The percentages of $\beta$-LG and $\alpha$-LA were approximately 3.89 and $1.09 \%$, respectively, in Salunke's study, versus 3.7 and $3.3 \%$, respectively, in our study. The protein fractions of $\mathrm{CMC}$ treatments during the $60 \mathrm{~d}$ of storage are shown in Figure 6. No significant differences $(P>0.05)$ were observed between the control, T1, and T2 at 0, 30, and $60 \mathrm{~d}$ of storage at $4^{\circ} \mathrm{C}$, although we observed a significant increase $(P<0.05)$ in NCN during $60 \mathrm{~d}$ of storage

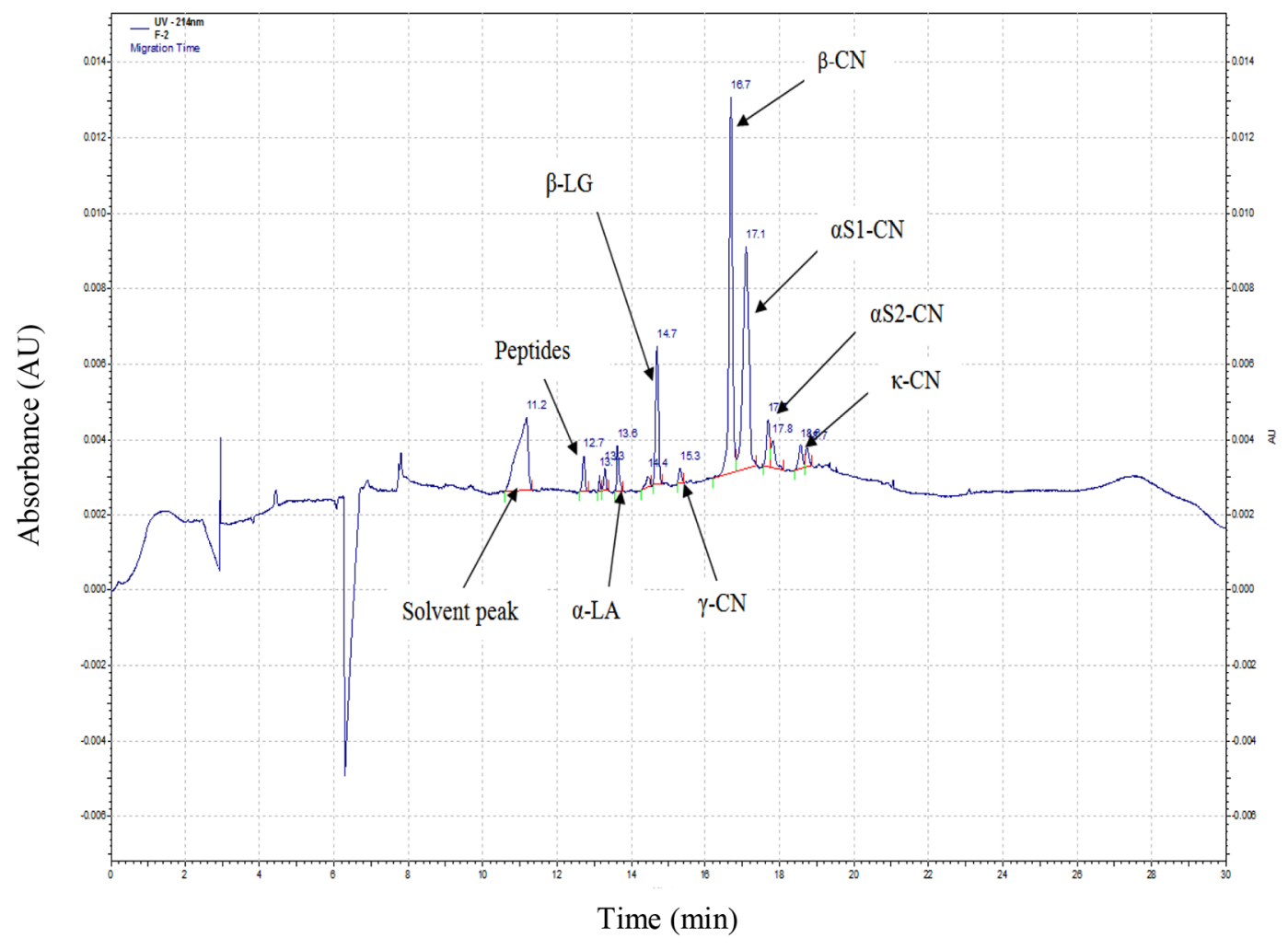

Figure 2. Capillary gel electrophoretogram of skim milk. AU = absorbance units. 


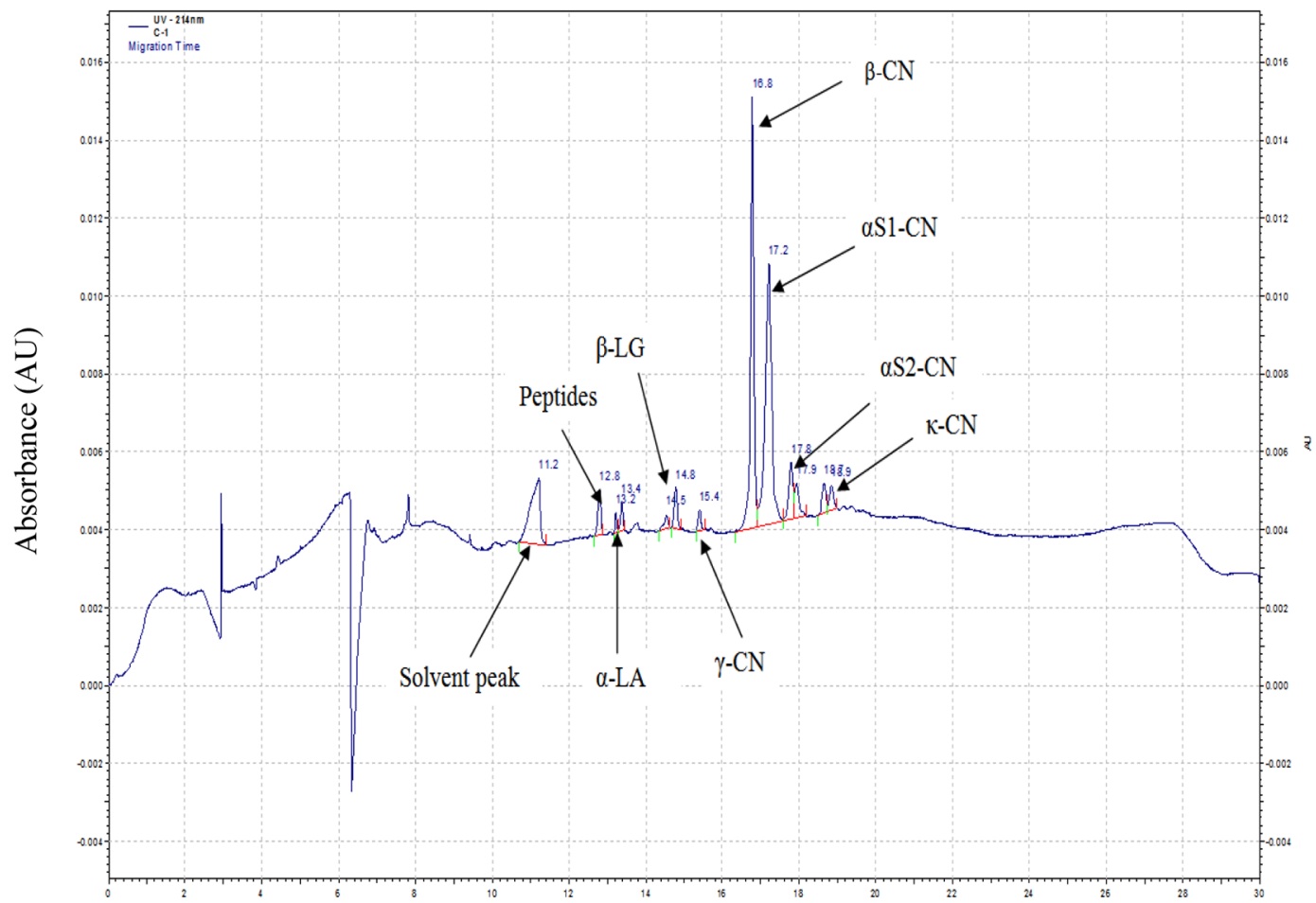

Time (min)

Figure 3. Capillary gel electrophoretogram of concentrated micellar casein, control. AU = absorbance units.

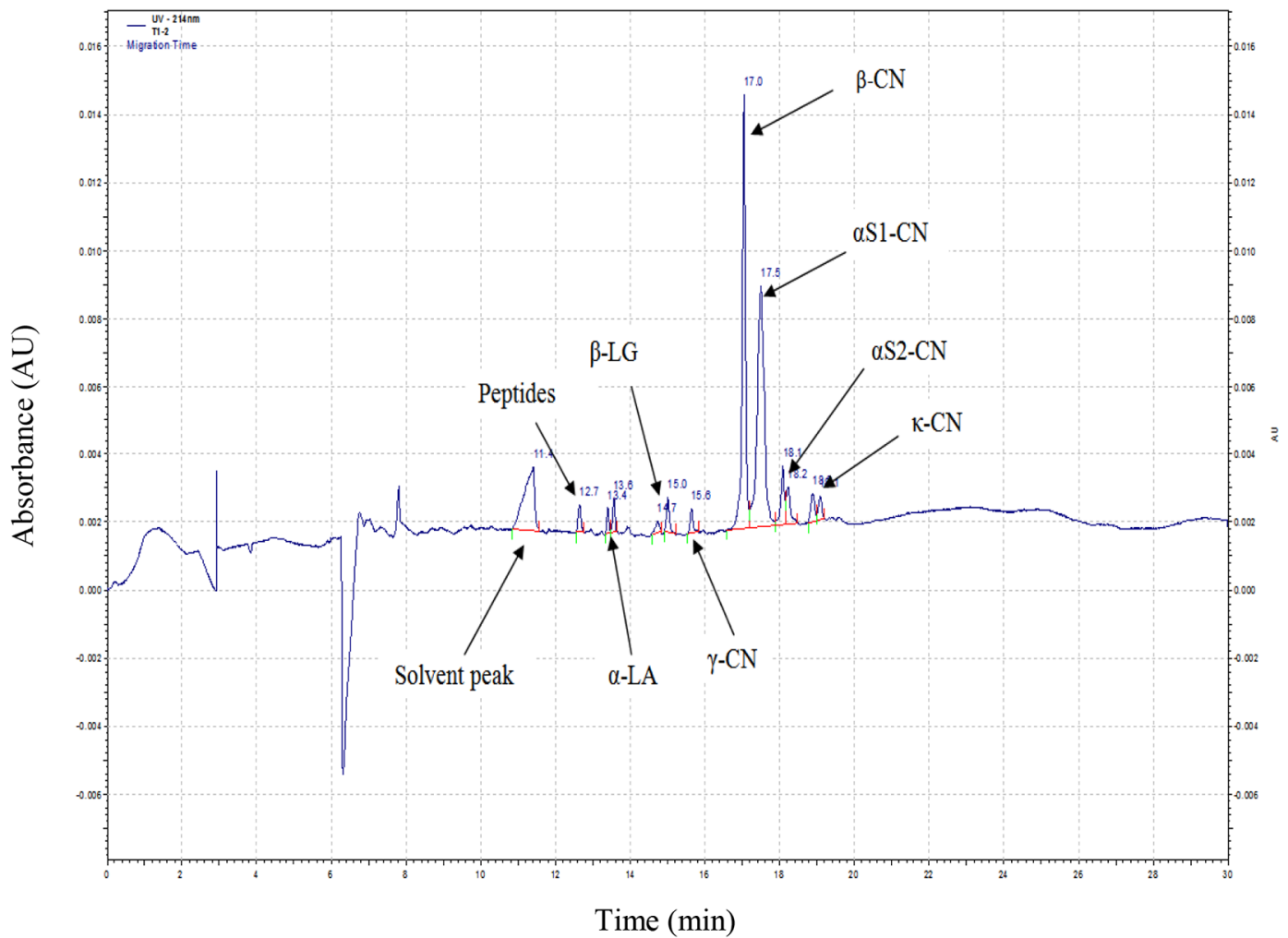

Figure 4. Capillary gel electrophoretogram of concentrated micellar casein (CMC) $\mathrm{T} 1$ (CMC $+1 \%$ sodium chloride). AU $=$ absorbance units. 


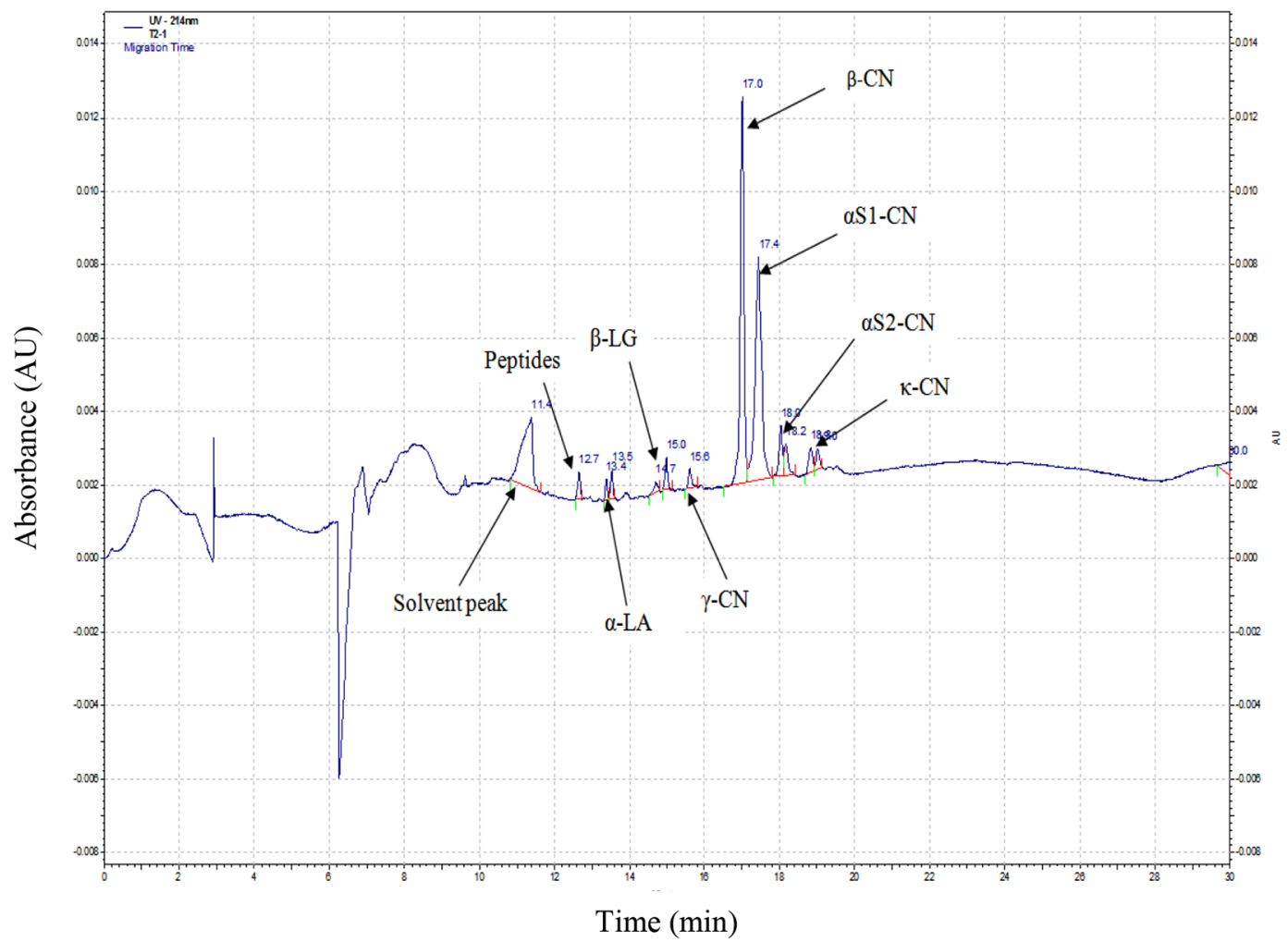

Figure 5. Capillary gel electrophoretogram of concentrated micellar casein (CMC) T2 (CMC+1\% sodium chloride and $1 \%$ sodium citrate). $\mathrm{AU}=$ absorbance units.

using Kjeldahl analysis (Table 6). This could be related to the fact that CGE is more accurate and determines each protein fraction individually.

Permeate. The protein fractions present in the permeate created during MF process are presented in Table 11. The percentages of $\beta$-LG and $\alpha$-LA content were calculated in the permeate of each stage. The percentages of $\beta$-LG and $\alpha$-LA in the first stage were approximately 70.0 and $26.9 \%$, respectively. Zulewska et al. (2009) reported that the percentages of $\beta$-LG and $\alpha$-LA in MF permeate were 76.3 and $23.7 \%$, respectively, in the first stage using a $3 \times \mathrm{CF}$ in GP ceramic membranes, which is close to our values. The percentages of $\beta-\mathrm{LG}$ and $\alpha-\mathrm{LA}$ in the second stage were 75.04 and $20.8 \%$, respectively, and 72.1 and $22.3 \%$ in the third stage. It has been reported that the relative percentages of $\beta$-LG to $\beta$-LG plus $\alpha$-LA in permeate were $71.5,73.0$, and $74.6 \%$ in the first, second, and third stages, respectively, with a $3 \times \mathrm{CF}$ using Isoflux membranes (Adams and Barbano, 2013). The relative

Table 10. Mean $(\mathrm{n}=3)$ relative protein fractions measured by using capillary gel electrophoresis of pasteurized skim milk and treatments of concentrated micellar casein (CMC)

\begin{tabular}{|c|c|c|c|c|c|c|c|c|c|c|}
\hline Treatment $^{1}$ & $\beta-\mathrm{CN}^{2}$ & $\alpha_{\mathrm{S} 1}-\mathrm{CN}^{2}$ & $\alpha_{\mathrm{S} 2}-\mathrm{CN}^{2}$ & $\kappa-\mathrm{CN}^{2}$ & $\gamma-\mathrm{CN}^{2}$ & $\alpha-\mathrm{LA}^{3}$ & $\beta-\mathrm{LG}^{3}$ & Peptides $^{4}$ & $\mathrm{CN}$ & SP \\
\hline Control & $36.97^{\mathrm{a}}$ & $39.15^{\mathrm{a}}$ & 8.59 & 4.40 & $1.63^{\mathrm{a}}$ & $3.30^{\mathrm{b}}$ & $3.75^{\mathrm{b}}$ & $2.19^{\mathrm{a}}$ & $90.74^{\mathrm{a}}$ & $7.06^{\mathrm{b}}$ \\
\hline $\mathrm{T} 1$ & $37.80^{\mathrm{a}}$ & $39.49^{\mathrm{a}}$ & 7.78 & 3.65 & $1.98^{\mathrm{a}}$ & $4.07^{\mathrm{b}}$ & $3.33^{\mathrm{b}}$ & $1.98^{\mathrm{a}}$ & $90.72^{\mathrm{a}}$ & $7.40^{\mathrm{b}}$ \\
\hline SEM & 0.91 & 0.97 & 0.26 & 0.18 & 0.35 & 0.40 & 1.57 & 0.07 & 1.93 & 1.94 \\
\hline SD & 1.82 & 1.94 & 0.53 & 0.36 & 0.71 & 0.80 & 3.15 & 0.13 & 3.86 & 3.88 \\
\hline
\end{tabular}

\footnotetext{
${ }_{\mathrm{a}, \mathrm{b}}$ Means in the same column not sharing a common superscript are different $(P<0.05)$.

${ }^{1}$ Control $=\mathrm{CMC} ; \mathrm{T} 1=\mathrm{CMC}+1 \%$ sodium chloride; $\mathrm{T} 2=\mathrm{CMC}+1 \%$ sodium chloride and $1 \%$ sodium citrate.

${ }^{2}$ Each fraction calculated as a percentage of total CN area.

${ }^{3}$ Each fraction calculated as a percentage of total serum protein (SP) area.

${ }^{4}$ Peptides $=$ peptide peaks $(10-20 \mathrm{kDa})$ other than $\alpha-\mathrm{LA}$ and $\beta$-LG.
} 
Table 11. Mean $(\mathrm{n}=3)$ relative protein fractions measured by using capillary gel electrophoresis of permeate during the 3 stages of microfiltration processing from skim milk

\begin{tabular}{|c|c|c|c|c|c|c|}
\hline Stage & $\beta-\mathrm{CN}^{1}$ & $\alpha-\mathrm{LA}^{2}$ & $\beta-\mathrm{LG}^{2}$ & Peptides $^{3}$ & $\mathrm{CN}$ & SP \\
\hline 1 & & $26.87^{\mathrm{a}}$ & $70.04^{\mathrm{b}}$ & 3.09 & & 96.91 \\
\hline 2 & 0.83 & $20.85^{\mathrm{b}}$ & $75.04^{\mathrm{a}}$ & 3.28 & 0.83 & 95.89 \\
\hline 3 & & $22.28^{\mathrm{b}}$ & $72.10^{\mathrm{ab}}$ & 5.62 & & 94.38 \\
\hline SEM & & 1.00 & 0.95 & 0.55 & & 0.52 \\
\hline $\mathrm{R}^{2}$ & & 0.82 & 0.58 & 0.54 & & 0.48 \\
\hline
\end{tabular}

${ }^{\mathrm{a}, \mathrm{b}}$ Means in the same column not sharing a common superscript are different $(P<0.05)$.

${ }^{1}$ Each fraction calculated as a percentage of total CN area.

${ }^{2}$ Each fraction calculated as a percentage of total serum protein (SP) area.

${ }^{3}$ Peptides $=$ peptide peaks $(10-20 \mathrm{kD})$ other than $\alpha-\mathrm{LA}$ and $\beta$-LG.

percentages of $\beta$-LG to $\beta$-LG plus $\alpha$-LA in the permeate of our study were $72.9,78.2$, and $76.4 \%$ in the first, second, and third stages, respectively, which are close to Adams and Barbano's values. These small differences may be related to the composition of skim milk, processing conditions, type of membranes, or experimental error (such as temperatures, flux, CF, and DF). Peptides increased, but not significantly $(P>0.05)$, from $3.09 \%$ in the first stage to $5.6 \%$ in the third stage. Interestingly, a small amount of $\beta-\mathrm{CN}(0.83 \%)$ was observed in the permeate of the second stage. It has been reported that the permeate of the first-stage MF had a $4.93 \%$ CN using GP ceramic membranes and $1.23 \%$ using UTP membranes (Zulewska et al., 2009). After each MF stage in our process, the retentate was cooled and kept at $4^{\circ} \mathrm{C}$ during cleaning the MF system. We hypothesized that $\beta-\mathrm{CN}$ is transferred from the $\mathrm{CN}$ micelles at $4^{\circ} \mathrm{C}$ with the addition of $\mathrm{DF}$ water. The amphiphilic nature (charged polar $\mathrm{N}$-terminal region and less polar C-terminal region) of $\beta$-CN allows it to transit from the micelle into the serum phase depending on temperature (O'Connell et al., 2003) during heating

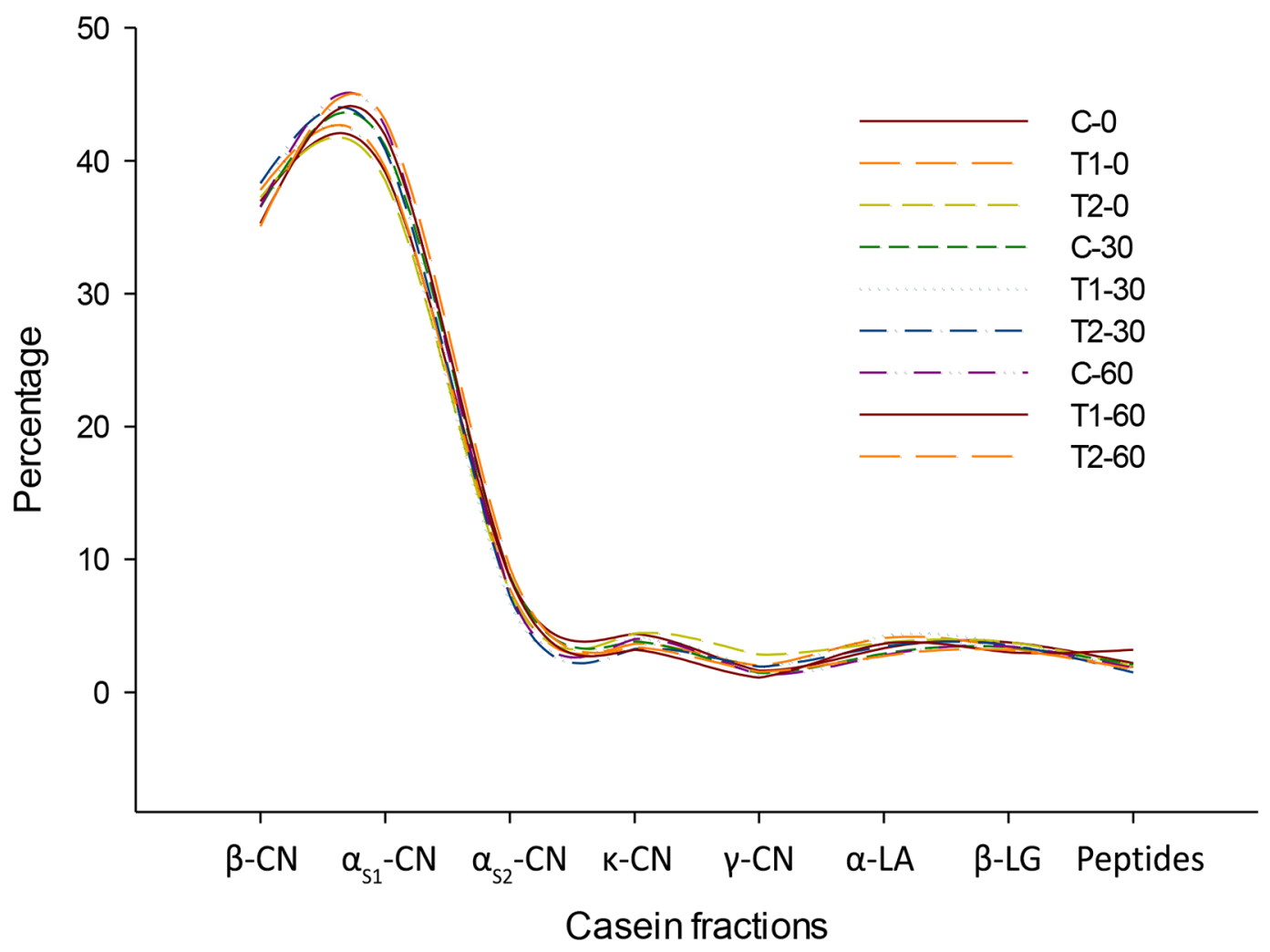

Figure 6. Mean $(\mathrm{n}=3)$ relative protein fractions $(\%)$ observed in capillary gel electrophoresis of concentrated micellar casein $(\mathrm{CMC})$ during $60 \mathrm{~d}$ of storage at $4^{\circ} \mathrm{C} . \mathrm{C}=\mathrm{CMC} ; \mathrm{T} 1=\mathrm{CMC}+1 \%$ sodium chloride; $\mathrm{T} 2=\mathrm{CMC}+1 \%$ sodium chloride and $1 \%$ sodium citrate. $0=$ immediately after manufacturing; $30=\mathrm{d} 30$ of storage; $60=\mathrm{d} 60$ of storage. 
the retentate to $50^{\circ} \mathrm{C}$ before $\mathrm{MF}$. We may not have held the $\mathrm{CMC}$ long enough at $50^{\circ} \mathrm{C}$ for the $\beta-\mathrm{CN}$ to transit back into the $\mathrm{CN}$ micelles. As a result, solubilized $\beta$-CN (which has low MW) passed through the membrane to the permeate in stage 2 .

\section{CONCLUSIONS}

A process to produce $\mathrm{CMC}$ with a 60 -d refrigerated shelf-life was developed. This study determined that CMC can be manufactured using a ceramic GP MF system with $>25 \%$ TS and $>95 \%$ CN $\%$ TP. The addition of sodium chloride or sodium citrate did not significantly $(P>0.05)$ affect the composition of $\mathrm{CMC}$ immediately after manufacturing (at d 0 ) and during the $60 \mathrm{~d}$ of storage at $4^{\circ} \mathrm{C}$. However, the NCN content increased significantly $(P<0.05)$ during $60 \mathrm{~d}$ of storage in all treatments. The TBC also increased significantly $(P<0.05)$ in all treatments during $60 \mathrm{~d}$ of storage at $4^{\circ} \mathrm{C}$. This indicates that the addition of those salts in $\mathrm{T} 1$ and $\mathrm{T} 2$ did not decrease the rate of proteolysis. The influence of the increase in NCN, as well as addition of sodium chloride or sodium citrate to CMC during storage on process cheese characteristics, will be evaluated in subsequent studies.

\section{ACKNOWLEDGMENTS}

The authors acknowledge and thank the Midwest Dairy Foods Research Center (St. Paul, MN) for their financial support. The authors have not stated any conflicts of interest.

\section{REFERENCES}

Adams, M. C., and D. M. Barbano. 2013. Serum protein removal from skim milk with a 3 -stage, $3 \times$ ceramic Isoflux membrane process at $50^{\circ} \mathrm{C}$. J. Dairy Sci. 96:2020-2034. https://doi.org/10.3168/jds .2012-6007.

Adams, M. C., and D. M. Barbano. 2016. Effect of ceramic membrane channel diameter on limiting retentate protein concentration during skim milk microfiltration. J. Dairy Sci. 99:167-182. https://doi .org/10.3168/jds.2015-9897.

Amelia, I., and D. M. Barbano. 2013. Production of an 18\% protein liquid micellar casein concentrate with a long refrigerated shelf life. J. Dairy Sci. 96:3340-3349. https://doi.org/10.3168/jds.2012 $-6033$.

Anema, S. G. 2009. The use of "lab-on-a-chip" microfluidic SDS electrophoresis technology for the separation and quantification of milk proteins. Int. Dairy J. 19:198-204. https://doi.org/10.1016/j idairyj.2008.11.001.

AOAC Internationa. 2000. Official Methods of Analysis. 17th ed. AOAC International.

Beckman, S. L., and D. M. Barbano. 2013. Effect of microfiltration concentration factor on serum protein removal from skim milk using spiral-wound polymeric membranes. J. Dairy Sci. 96:61996212. https://doi.org/10.3168/jds.2013-6655.

Beckman, S. L., J. Zulewska, M. Newbold, and D. M. Barbano. 2010. Production efficiency of micellar casein concentrate using polymer- ic spiral-wound microfiltration membranes. J. Dairy Sci. 93:45064517. https://doi.org/10.3168/jds.2010-3261.

Creamer, L. K., and T. Richardson. 1984. Anomolous behaviour of bovine $\alpha_{\mathrm{S1}^{-}}$and $\beta$-caseins on gel electrophoresis in sodium dodecyl sulfate buffers. Arch. Biochem. Biophys. 234:476-486. https://doi .org/10.1016/0003-9861(84)90295-9.

Farrell, H. M. Jr., R. Jimenez-Flores, G. T. Bleck, E. M. Brown, J. E. Butler, L. K. Creamer, C. L. Hicks, C. M. Hollar, K. F. Ng-KwaiHang, and H. E. Swaisgood. 2004. Nomenclature of the proteins of cows' milk-Sixth revision. J. Dairy Sci. 87:1641-1674. https://doi .org/10.3168/jds.S0022-0302(04)73319-6.

FDA (Food and Drug Administration). 2009. Grade "A" Pasteurized Milk Ordinance. Publication No. 229. US Dept. of Health and Human Services, Public Health Service.

Fox, P. F., and P. L. H. McSweeney. 1998. Dairy Chemistry and Biochemistry. Kluwer Academic/Plenum Publishers.

Govindasamy-Lucey, S., J. J. Jaeggi, M. E. Johnson, T. Wang, and J. A. Lucey. 2007. Use of cold microfiltration retentates produced with polymeric membranes for standardization of milks for manufacture of pizza cheese. J. Dairy Sci. 90:4552-4568. https://doi .org/10.3168/jds.2007-0128.

Hammam, A. R. A., S. I. Martínez-Monteagudo, and L. E. Metzger. 2021. Progress in micellar casein concentrate: Production and applications. Compr. Rev. Food Sci. Food Saf. 20:4426-4449. https:/ /doi.org/10.1111/1541-4337.12795.

Hammam, A.R.A., and L.E. Metzger. 2018. Production and storage stability of liquid micellar casein concentrate. J. Dairy Sci 101(Suppl. 2):8. (Abstr.)

Hurt, E., and D. M. Barbano. 2010. Processing factors that influence casein and serum protein separation by microfiltration1. J. Dairy Sci. 93:4928-4941. https://doi.org/10.3168/jds.2010-3121.

Hurt, E., J. Zulewska, M. Newbold, and D. M. Barbano. 2010. Micellar casein concentrate production with a $3 \times, 3$-stage, uniform transmembrane pressure ceramic membrane process at $50^{\circ} \mathrm{C}$. J. Dairy Sci. 93:5588-5600. https://doi.org/10.3168/jds.2010-3169.

Lawrence, N. D., S. E. Kentish, A. J. O'Connor, A. R. Barber, and G. W. Stevens. 2008. Microfiltration of skim milk using polymeric membranes for casein concentrate manufacture. Separ. Purif. Tech. 60:237-244. https://doi.org/10.1016/j.seppur.2007.08.016.

Lu, Y., D. J. McMahon, L. E. Metzger, A. Kommineni, and A. H Vollmer. 2015. Solubilization of rehydrated frozen highly concentrated micellar casein for use in liquid food applications. J. Dairy Sci. 98:5917-5930. https://doi.org/10.3168/jds.2015-9482.

Marella, C., V. Sunkesula, A. R. A. Hammam, A. Kommineni, and L. E. Metzger. 2021. Optimization of spiral-wound microfiltration process parameters for the production of micellar casein concentrate. Membranes (Basel) 11:656. https://doi.org/10.3390/ membranes11090656.

Miralles, B., B. Bartolome, L. Amigo, and M. Ramos. 2000. Comparison of three methods to determine the whey protein to total protein ratio in milk. J. Dairy Sci. 83:2759-2765. https://doi.org/ 10.3168/jds.S0022-0302(00)75171-X.

Miralles, B., M. Ramos, and L. Amigo. 2003. Influence of proteolysis of milk on the whey protein to total protein ratio as determined by capillary electrophoresis. J. Dairy Sci. 86:2813-2817. https:// doi.org/10.3168/jds.S0022-0302(03)73878-8.

Muir, D. D. 1996. The shelf-life of dairy products: 3. Factors influencing intermediate and long life dairy products. Int. J. Dairy Technol. 49:67-72. https://doi.org/10.1111/j.1471-0307.1996.tb02493 x.

Mulvihill, D. M., and M. P. Ennis. 2003. Functional milk proteins: Production and utilization. Pages 1175-1228 in Advanced Dairy Chemistry-1 Proteins. P. F. Fox, ed. Springer US.

Nasser, S., P. De Sa Peixoto, A. Moreau, T. Croguennec, F. Bray, C. Rolando, F. J. Tessier, A. Hédoux, and G. Delaplace. 2018. Storage of micellar casein powders with and without lactose: Consequences on color, solubility, and chemical modifications. J. Agric. Food Chem. 66:10274-10282. https://doi.org/10.1021/acs.jafc.7b06147.

O'Connell, J. E., V. Y. Grinberg, and C. G. de Kruif. 2003. Association behavior of $\beta$-casein. J. Colloid Interface Sci. 258:33-39. https: //doi.org/10.1016/S0021-9797(02)00066-8. 
Rollema, H. S., and D. D. Muir. 2009. Casein and Related Products. Wiley-Blackwell.

Salunke, P. 2013. Impact of transglutaminase on the functionality of milk protein concentrate and micellar casein concentrate. PhD Diss. Dairy and Food Science Department, South Dakota State University.

Salunke, P., C. Marella, and L. E. Metzger. 2011. Use of capillary gel electrophoresis for quantification of individual milk proteins in ultra- and microfiltration retentate. J. Dairy Sci. 89(E-Suppl. 1):58. (Abstr.)

Singh, H. 1995. Heat-induced changes in casein, including interactions with whey proteins. Pages 86-104 in Heat-Induced Changes in Milk. P. F. Fox, ed. International Dairy Federation.

Tremblay-Marchand, D., A. Doyen, M. Britten, and Y. Pouliot. 2016. A process efficiency assessment of serum protein removal from milk using ceramic graded permeability microfiltration membrane. J. Dairy Sci. 99:5230-5243. https://doi.org/10.3168/jds.2016-10914.

Walstra, P., and R. Jenness. 1984. Dairy Chemistry and Physics. John Wiley and Sons.

Wehr, H. M., and J. F. Frank. 2004. Standard Methods for the Examination of Dairy Products. 17th ed. American Public Health Association.
Zhang, H., and L. E. Metzger. 2011. Noncasein nitrogen analysis of ultrafiltration and microfiltration retentate. J. Dairy Sci. 94:21182125. https://doi.org/10.3168/jds.2010-3690.

Zulewska, J., and D. M. Barbano. 2014. The effect of linear velocity and flux on performance of ceramic graded permeability membranes when processing skim milk at $50^{\circ}$ C. J. Dairy Sci. 97:26192632. https://doi.org/10.3168/jds.2013-7635.

Zulewska, J., M. Newbold, and D. M. Barbano. 2009. Efficiency of serum protein removal from skim milk with ceramic and polymeric membranes at $50^{\circ}$ C. J. Dairy Sci. 92:1361-1377. https://doi.org/ $10.3168 /$ jds.2008-1757.

\section{ORCIDS}

Ahmed R. A. Hammam @ https://orcid.org/0000-0002-2388-2726

Lloyd E. Metzger (ํ) https://orcid.org/0000-0003-3929-4539 